\title{
Communication deficits in a case of 22q11.23 Duplication Syndrome with a deletion in $7 q 31$ encompassing FOXP2
}

\author{
Verónica Moreno-Campos* and Antonio Benítez-Burraco** \\ *Universidad de Valencia \\ **Universidad de Sevilla
}

\begin{abstract}
Copy number variants (CNVs) found in individuals with communication deficits provide a valuable window to the genetic causes of problems with language and more generally, to the genetic foundation of the human-specific ability to learn and use languages. In this paper, we report in detail on the language and communication problems of a patient with a microduplication in $22 \mathrm{q} 11.23$ and a microdeletion in 7q31 encompassing FOXP2. The proband exhibits severe speech problems, moderate comprehension deficits, and quite preserved pragmatic abilities, using gestures to compensate most of her expressive problems. This profile is compatible with the deficits found in patients with similar CNVs, particularly, with people bearing microdeletions in $7 \mathrm{q} 31$.
\end{abstract}

Keywords: FOXP2 gene; 22q11.23 microduplication; 7q31 microdeletion; language impairment; communication deficits

\section{Introduction}

Copy number variants (CNVs) found in individuals with communication deficits provide a valuable window to the genetic causes of problems with language and more generally, to the genetic foundation of the human-specific ability to learn and use languages. To date, dozens of CNVs with an impact on communication abilities have been described (see Gialluisi et al., 2016, among many others, for review). Delving into the deficits and the strengths of patients in the communication domain is necessary to achieve more robust links between specific genes and aspects of language processing. In this paper, we report in detail on the language and communication problems of a girl with a microduplication in 22q11.23 and a microdeletion in 7q31 encompassing FOXP2, a gene which has been consistently related to language problems. 
Deletions in 22q11.2 result in a well-known condition (the 22q11.2 Deletion Syndrome), which has been characterised in depth at a genetic level ( $\mathrm{Du}$ et al., 2020), a neurobiological level (Zinkstok et al., 2019), and a phenotypical level (Sullivan, 2019), including the domain of language (Solot et al., 2019). By contrast, there are very few descriptive studies of features resulting from the 'mirror' condition, namely, the 22q11.2 Duplication Syndrome. The first cases were described relatively recently and date back to 1999 and 2003, respectively (Edelman et al., 1999, Ensenauer et al., 2003). Seemingly because of the limited number of studies that are currently available, the $22 \mathrm{q} 11.2$ Duplication Syndrome is still regarded to exhibit a variable presentation, with affected individuals showing a range of different features with a diverse degree of severity. Some studies have tried to establish a correlation between the genotype and the phenotype (e.g. de La Rochebrochard et al., 2006, Dupont et al., 2014, Yu et al., 2019). Individuals with language impairment and/or neurodevelopmental comorbid disorders have been reported (e.g. Courtens t al., 2008, Chang, 2015, Puvabanditsin et al., 2015, Kylat,, 2018, ValenciaPeña et al., 2020). Nonetheless, a precise characterization of the language profile of patients is still pending.

Something similar can be said about the $7 \mathrm{q} 31$ region. This is part of a hot spot for language and communication problems (Schneider et al. 2012). However, we still lack a precise characterization of the problems exhibited by subjects with deletions in this region. Some studies point to the presence of broad neurodevelopmental deficits (Gimelli et al., 2014), whereas others are suggestive of verbal production difficulties (Zeesman et al., 2006, Lennon et al., 2007, Palka, 2011), and/or delayed speech and language (Rieger et al., 2020). With regards to the putative genetic causes of the observed deficits, most studies suggest a correspondence between language problems and the happloinsuficiency 
of the FOXP2 gene. FOXP2 is a well-known candidate for speech and language impairment (Vargha-Khadem, et al., 2005, Kurt et al., 2012, Graham et al., 2015). This gene plays a role in neuron proliferation, differentiation, and migration in selected brain areas important for language processing (Tsui et al., 2013, Chiu et al., 2014, GarcíaCalero et al., 2016). More specifically, the gene has been suggested to contribute to auditory-motor association learning (Kurt et al., 2012) and the transition from declarative to procedural performance (Schreiweis et al., 2014, Chandrasekaran et al., 2015). Some studies have suggested the involvement of other genes beyond FOXP2 in the language and communicative deficits exhibited by subjects with deletions of the $7 \mathrm{q} 31$ region (Zhao et al., 2016). Nonetheless, no studies to date have investigated in depth the possible impact of microdeletions in $7 \mathrm{q} 31$ in the broader area of communication. Communication is the fundamental sphere for social interaction, entailing the holistic interaction between individual's cognitive, linguistic, and social skills.

In this paper, we report in detail on the language and communication problems of a patient with a microduplication in 22q11.23 and a microdeletion in $7 \mathrm{q} 31$ encompassing FOXP2. The main contribution of our work is the precise characterization of the communicative profile of the patient (beyond her language deficits and strengths), which be found important, as noted, for a better understanding of the interactional problems showed by people bearing these complex CNVs.

\section{Material and methods}

\section{Microarrays for whole-genome CNVs search and chromosome aberrations analysis}

The DNA from the patient was hybridized on a CGH platform (Agilent Technologies). The derivative log ratio spread (DLRS) value was 0.25 . The platform included 750.000 
probes. Data were analyzed with the Chromosome Analysis Suite (ChAS) v. 4.0.0.385 from Applied Biosystems $(\mathcal{C}$ using CytoScan750K_Array Simple Analysis, NA33.2. The SNP QC was $>15$ and the Waviness $\mathrm{SD}<0.12$.

\section{Linguistic and cognitive assessment}

The global developmental profile of the girl was evaluated with the Spanish version of the Portage Developmental Guide (PDG) (Bluma et al., 2004) and the BOEHM test of basic concepts (BTBC-3) (Boehm, 2000).

The girl's global linguistic skills were evaluated with the Spanish versions of the Peabody Picture Vocabulary Test (PPVT-3) (Dunn et al., 2006). Her receptive comprehension abilities were evaluated with the Token Test Short-Form (TT) (De Renzi et al., 1978) and with visual and oral narrative stories prepared ad hoc. The Registro Fonológico Inducido test [Elicited Phonological Register] (RFI) (Monfort et al., 1988) was used to achieve a detailed knowledge of the girl's phonological awareness. Her voice profile was analysed with the Estill Voiceprint Plus program (2020). Finally, to evaluate her communication abilities, we analysed three different pragmatic categories in three conversational recordings of the proband, relying on the Protocolo Rápido de Evaluación Pragmática (PREP-R) (Martínez-Urquiza et al., 2015). Because of the severe deficits of the proband in the expressive domain, we also relied on the motor expression subtest of The Illinois Test of Psycholinguistic Abilities (ITPA) (Kirk et al., 2009) to evaluate the proband's ability to use gestures for communicating.

We now provide a brief characterization of the tests mentioned above.

\section{The Portage Developmental Guide (PGD)}

This is an assessment test aimed to determine the general abilities of children from birth to six years of age. It is organised around five developmental areas: socialization, 
language, self-development, cognition, and motricity. These domains are evaluated by a mixture of direct observation and elicited direct instructions to the child.

The BOEHM test of basic concepts (BTBC)

This test evaluates basic abilities that are needed at school success, including language comprehension skills and broad cognitive development. It is aimed for children from 3 to 6 years old. It examines 26 basic concepts via coloured drawings. The evaluator provides a verbal description to the child and she must point to the correct image among three of them.

\section{The Peabody Picture Vocabulary Test (PPVT-3)}

This test is aimed to assess the correct acquisition and the achieved level of receptive vocabulary in individuals from 2.5 to 90 years old. It consists of 192 items. After hearing a word, the subject is asked to point to one of four different coloured drawings. This test also enables to conduct a rapid screening of difficulties with language or abnormal verbal behaviours.

\section{Token Test (TT)}

This test aims to identify subtle auditory comprehension deficits in non-verbal patients. This is a gestural test. We used the short version of the test, which comprises 36 items only. The proband has to follow verbal instructions, from simple to complex commands, involving tokens which differ in colour, form (e.g. squares vs. circles) and size (e.g. large vs. small).

\section{Illinois test of Psycholinguistic Abilities (ITPA)}

The motor expression subtest of the ITPA evaluates the proband's ability to convey meanings about actions through gestures and body changes that demand a good command 
on gross psychomotricity skills. This subtest can be administered to children from 3 to 10 years old. 14 concepts related to specific gestures and motor actions are evaluated. The experimenter asks the child to reproduce the gesture or the movement that she usually associates to a particular concept (for example, the gesture of hanging a telephone after hearing the word 'telephone'). We did not administer other subtests of the ITPA because our proband was mostly speechless.

\section{Narrative stories}

Three stories were created ad hoc to evaluate the proband's ability to understand a narrated story. Each narration consisted of a brief text (around 45 words) that was read to the proband by the experimenter, using a drawing as an ancillary material. Texts contained simple sentences only, with just one single verb. The first text was a descriptive text, reporting on characters and their interests, the second text was a narrative text, telling a story about a play-situation between two children, the third text was a complex narration, describing how a child became lost in a forest. For each text, two questions were asked to the proband, from a total of six different types of questions: textual questions, inference questions, yes/no question, identification questions ('who?'), questions with two possible answers, and open questions.

\section{Elicited Phonological Register (RFI)}

This test assesses phonological and articulatory abilities of Spanish-speaking children between 3 and 7 years old. This is an elicited (word) production and repetition test. Word production is elicited by showing the child different pictures that she has to name. If the child is unable to generate the correct name by herself, the experimenter will provide the appropriate name and will ask the child to repeat it. The test comprises every possible 
sound of the Spanish language, so that it can be used to detect dyslalia as well as phonological impairment.

\section{Estill Voiceprint Plus program}

Estill Voiceprint Plus is a real-time spectral analysis program that enables to display, record, and playback the human voice. It provides meaningful information about the subject's pitch and voice quality. Voice samples from the proband were collected in three different settings: during a free-playing activity, while speaking with her parents or the speech therapist, and in an elicited task, in which the proband was asked to repeat several utterances.

\section{Protocolo Rápido de Evaluación Pragmática (PREP-R)}

This protocol is used to assess the proband's broad communication skills. It evaluates, in the context of a regular interaction with the speech therapist, whether the subject is able to produce utterances with the appropriate ilocutive force, but also if she has acquired the needed skills to be a competent interlocutor. Interactions were recorded to also analyse paratextual and non-linguistic elements (prosody, gestures, body language, etc.). Three different interactions of around 10 minutes were examined, each representing a different communication setting: playing at home, in a session with the speech-therapist, and playing with a habitual conversational partner.

\section{Results}

\section{Clinical history}

The proband is a girl that was fertilised in vitro from the egg of a 40-year-old mother and the sperm of a 62-year-old father. Both parents are monolingual in Spanish. The baby was delivered by caesarean section after 37 weeks of pregnancy. At birth, her weight was 
$3450 \mathrm{~g}$ (65th percentile), her height was $50 \mathrm{~cm}$ (54th percentile), and her occipitofrontal circumference was $37 \mathrm{~cm}$ (98th percentile). The Apgar scores were 9 (at 1') and 10 (at $\left.5^{\prime}\right)$. The pregnancy was uneventful. The girl started to walk at 22 months of age and she did not attend school until she was 3 years old. At that age, the paediatrician alerted the parents of a possible developmental delay. Then, at the age of 3 years and 2 months, the proband started to attend a speech-therapy clinic. At that moment, she was reported to suffer from a severe developmental delay (she was only able to produce vocalisations of /a/, /e/ and she mostly interacted with others using gestures). Moreover, she exhibited noteworthy behavioural disturbances, as she was unable to maintain sustained attention for long periods, even during playing activities. Moreover, she showed reduced tolerance to frustration, as well as tantrums and disruptive behaviours .

At the time of the assessment for the present paper, the proband was 5 years and 9 months old. She was attending the 3rd grade of kindergarten in an ordinary school, although she was receiving external aid from a speech therapist 3 days a week.

\section{Genetic findings}

A comparative genomic hybridization array (array-CGH) was performed when the proband was 4 years and 3 months old. The array confirmed the presence of a deletion of $12,236 \mathrm{Mb}$ in the $7 \mathrm{q} 31$ region $(\operatorname{arr}[\operatorname{hg} 19] 7 \mathrm{q} 31.1 \mathrm{q} 31.3(113317103-125553025 \times 1)$, predicted to be pathological, and a duplication of $1,426 \mathrm{Mb}$ in the $22 \mathrm{q} 11.23$ region (arr[hg19] 22q11.23 (23654063-25080077x3), predicted to be of uncertain significance (Figure 1).

[FIGURE 1 NEAR HERE] 


\section{Detailed cognitive and language assessment}

\section{General cognitive development}

Considering the scores obtained in the PGD (Supplemental file), the proband, in the selfdevelopment section, is at the first milestones of the 4-5-year-old level: whereas she is able to undress herself, perform self-cleaning, or feed herself under given orders, she is unable to perform any of these tasks in an automated and independent way. The items in the cognition section of the test place her at a developmental level of 3-4 years of age, as she is able to categorise similar elements, but not to reproduce or deduce serial elements. Motor development corresponds to a developmental age of 3-4 years, with gross motor skills being less impaired than fine motor skills, possibly due to her congenital clinodactyly in the index finger of the right hand. In the domain of communication, the proband is at the first stage of socialisation, with an equivalent age of 2-3 years, as she does not interact with other children while playing. She is not able either to maintain the necessary joint attention for successfully performing joint tasks. In the domain of language, she scored like children between 1 and 2 years old as she just produces a restricted set of holophrastic utterances.

In the BOEHM test, the proband obtained a direct score of 15 (1st centile) (Supplemental file). Most of the correct answers concern to the spatial category and, to a lesser extent, to the quantity category. By contrast, the proband failed in all categories involving temporal concepts. It is important to note that this test demands a significant capacity for abstraction and for inference, as for performing correctly in the test, the child needs to infer taxonomic relationships between subordinate (more concrete) and superordinate (more abstract) elements).

\section{Language development}


1. Speech. The mean fundamental frequency of the proband 's voice is $450 \mathrm{hz}$.

Interharmonic noise was detected, with noise/harmonics ratio (NHR) values above normal. Glottal onset, as well as increased closed phase of the phonatory cycle were observed, with a maximum phonatory time of 1.5 seconds (Figure 2).

[FIGURE 2 NEAR HERE]

The girl exhibited difficulties for initiating the utterance of words, because of an abnormally high prephonatory activity. This mostly resulted from an active position of the prephonatory laryngeal structure, caused by an excess of muscular contraction, as well as an abnormal closure of the glottic space and the supraglottic cavities. Overall, this modifies the transglottic airflow, increasing the phonatory pressure threshold necessary for putting the vocal folds into movement. The resulting emission, which is typically short, hard and with a high pitch, impacts negatively on the most superficial layer of the vocal folds (the epithelium or covering) and consequently, fatigues both the intrinsic and extrinsic muscles of the larynx. Regarding her voice's prosody, the proband was unable to confer the needed intonation to linguistic utterances either in spoken or even sung language. When trying to reproduce the prosodic pattern of a question, with its characteristic rising pitch at the end, the girl always ended up screaming.

In the RFI test the proband was only able to utter isolated phonemes (Supplemental file). In no case was she able to produce any of the requested words, either by spontaneous production or by repetition. By herself, the girl was only able to generate the voiceless implosive guttural phoneme $/ \mathrm{k} /$, the voiceless and voiced bilabial stop phonemes $/ \mathrm{p} /$ and $/ \mathrm{b} /$, and the alveolar and bilabial nasal phonemes $/ \mathrm{n} /$ and $/ \mathrm{m} /$. Regarding the syllable, the proband only managed to combine some of these consonants with the open vowel /a/ except for the combination /no/ (an negative particle in Spanish). In repetition tasks, she 
was able to utter the voiceless fricative phoneme/s/, but she was unable to combine it with other sounds.

2. Language comprehension. Because of the severe expressive problems exhibited by the proband, we evaluated in detail her verbal comprehension abilities. According to the scores obtained in the PPVT-3 test, our proband has an associated IQ of 55, which is suggestive of a delay of 2 years (Supplemental file). In the Token Test task, the proband performed correctly in tasks evaluating shape-plus-object associations (e.g. 'touch a blue square') and shape-object-size associations (e.g. 'touch the small yellow circle'). However, she failed in tasks evaluating shape-object-size associations, particularly if they involved some sort of spatial displacement or rotation (e.g. "place the big white triangle on a blue square'). Overall, she obtained a direct score of 23 (supplemental file), which is indicative of moderate comprehension problems. In the story comprehension task, the proband answered correctly $83 \%$ of the questions about characters (e.g. 'Who went to the forest?') and $33 \%$ of the questions about the plot (e.g. 'Where were the children playing?'), but she was unable to answer any of the inferential questions (e.g. 'Why does Eric start to cry?'). With regards to the type of question, the girl provided correct answers to closed, polar (i.e. yes/no) questions (e.g. 'Did Tomás like the cakes?'), as well as questions about the characters' identity (e.g. 'Who is Ana?'), but failed in questions with two possible answers (e.g. 'What did the children drink: juice or water?'), as well as in open questions (e.g. 'How did Ana feel when she found her house?').

3. Communication abilities. As noted, we were particularly interested in assessing not only the structural language deficits (and strengths) exhibited by the proband, but also her broader communicative (dis)abilities. A reason is that, as also highlighted in the Introduction, much less is known about language use in children bearing similar CNVs to the ones found in our proband. Another reason is that in spite of the proband's marked 
deficits in the oral-expressive domain, her comprehension abilities were quite preserved and she relied on gestures to convey some basic information.

We corrobored that our proband is a successful interlocutor, who manages to convey her basic needs in effective ways. She has mastered some rudimentary rules for social interaction and makes up for its linguistic shortcomings through non-verbal communication devices. In terms of enunciative pragmatics, the girl is a competent sender. Although she is unable to utter full linguistic structures, she succeeds in conveying the intentionality of her actions. In $87 \%$ of the conversational turns, she got the expected reaction from her interlocutor. Clearly, for this she counts on the inferential abilities of her sender, who is usually a person from her close environment who knows the girl well. Nonetheless, she also exhibits a notable ability for communicating via gestures (mostly deictic cues pointing to surrounding objects) during interactions. Failed communication usually results in disruptive behaviours by the proband, such as crying or aggression towards the receiver.

Textual pragmatics is limited to monolexematic utterances acting as proto-sentences (i.e. holophrases). Most frequent utterances are 'papa [dad]', 'mama [mum]' and 'no [no, not]'. The first two utterances serve not only for identifying her parents, but also for requesting (e.g. demanding the completion of a particular task). For example, the proband can be playing with her mother and say 'pa pa' to communicate that she wants to bring the activity to an end. Or during a session with her speech therapist, she can utter 'ma ma's while pointing to the door to indicate that she wants to finish the session.

As noted, most of the speech acts conveyed by the proband are never verbalized, so that scarcely $10 \%$ can be typified as non-propositional locutionary acts. She does not properly manage pauses, silences or prosody during her intra-turns, and she shows no metapragmatic awareness regarding these elements. Notwithstanding, the proband is 
capable of complementing vocalisations with compensatory gestures, in order to qualify or reinforce the illocutive force of her speech acts. This is particularly notable considering her noteworthy motor problems, as corroborated by the motor expression subtest of the ITPA: she failed to perform any of the proposed praxias, neither in spontaneous behaviour tasks nor in repetition after modelling tasks). Although, as noted, many of her gestures fulfil a deictic function (in many cases accompanied by the prolonged vocalisation of /a/), gestures can convey richer meanings, as shown in Table 1.

\section{[TABLE 1 NEAR HERE]}

With regards to interactional pragmatics, it is worth highlighting that our proband is able to maintain prolonged eye contact with her interlocutor during the interactions in order to confirm both listening and comprehension by the other. Her interactions are further characterised by a high turn agility, facilitated by the proband's gestural responses. The girl always takes her turns at the correct moment, It should be acknowledged that interactions are usually facilitated by the interlocutors' behaviour, who address the child in short turns and with closed yes/no questions, to facilitate the child's understanding of what is being conveyed.

\section{Discussion}

The detailed evaluation of the language and communication (dis)abilities exhibited by the clinical case described in this paper suggests that the proband is able to communicate in a significant way in spite of their severe (mostly expressive) language deficits. Specifically, she succeeds in conveying the appropriate illocutive force to her speech acts during a conversation. 
In the domain of speech, the proband presents severe articulatory deficiencies that impact negatively on the intelligibility of her discourse Voice quality features significant alterations an inability to lengthen the phonatory range, as well as difficulties for starting phonation, that seemingly result from an abnormal position of the larynx at the onset of articulation. Additionally, she has difficulties for modulating pitch contour, so that voice effects with a paralinguistic function are absent. However, in spite of these speech problems, the girl relies on gestures to complement her oral productions, so that a receiver can easily infer the child's needs or demands, particularly, after previous exposition to the proband 's gestures. Proband's pragmatic abilities are higher than grammatic, it is consistent with FOXP2 described cases, where a 2 years-old difference was founded between verbal and non-verbal abilities, as in our case (García-Bellido et al., 2009, Moralli et al., 2015). This grammatic delay is not present in 22q11.2 Duplication Syndrome: a case of verbal IQ higher that non-verbal IQ was described in Solot et al., (2019).

Cognitive evaluation of the proband suggests that the child has achieved some ability for categorising, as performs adequately in conceptualisation tasks demanding a correspondence between objects and words (significant-meaning correspondence, as in 'take the yellow square'), although she is not able to make abstract representations (inferences about other people's feelings), as those involving two linguistic elements (as 'take the red circle and put it over the white square). The proband is able to learn some basic semantic relations, as with words with conveying concrete meanings, but only if they refer to objects or circumstances that are in surrounding context. Also, she is able to generalise knowledge from previous experience (answering correctly to e.g. 'how can we open the door?'). Finally, although she can recognize feelings, she only takes them in consideration for satisfying her own needs. All these features suggest that she is still in 
an early stage of cognitive development, suffering from a mild-to-severe cognitive delay ( 2 years below their peers matched on chronological age) impacting mostly on expressive language, with the sensoriomotor system acting as the main source knowledge acquisition. Interestingly, Kurt and colleagues (2012) have related one of the genes deleted in the proband, namely FOXP2, to sensory-motor association learning.

Table 2 shows a comparison of the abnormal features found in our proband with cases of mutations in the FOXP2 gene, cases of 22q11.2 Duplication Syndrome, and cases of deletions of the $7 \mathrm{q} 31$ region. As noted, the problems found in our proband parallel, in part, the findings by Shriberg and colleagues (2006) in two cases of mutations in the FOXP2 gene. However, in our proband we did not find evidence of spastic features, nor does the child try to articulate sounds that are similar to the ones she is unable to generate, as observed by Shriberg and colleagues. By contrast, the articulation errors committed by our case consist mostly of substitution errors or omission errors. Moreover, paralinguistic elements are totally absent in her discourse. Still, we regard the articulatory problems exhibited by our proband as compatible with the central FOXP2 phenotype (Laffin et al., 2012, Turner et al., 2013), which is a form of verbal apraxia entailing difficulties to produce, integrate, and combine phonemes into syllabic sequences. As noted by Morgan and colleagues (2016), this is a core symptom not only in the literature about $F O X P 2$, but also about the deletion of the $7 \mathrm{q} 31$ region, which commonly results in oral apraxia, phonologic disorder, and/or expressive language disorder. Several authors (e.g. Zeesman et al., 2006, Lennon et al., 2007, Palka et al., 2011) have suggested that a 7q31 Deletion Syndrome (resulting from deletions encompassing FOXP2) can be posited, giving rise to the common linguistic manifestations referred to above, but also resulting in preserved pragmatic abilities in socially comfortable situations, as found in our proband. 


\section{[TABLE 2 NEAR HERE]}

That said, our results are also consistent with the verbal communication problems that are secondary to the 22q11.2 Duplication Syndrome, as described by Yu et al. (2019), who found articulation problems secondary to motor deficits in 2 out of 3 of their subjects. However, in our proband, we did not find evidence of neurodevelopmental problems (growth, weight, or height anomalies) or hypotonia. Consequently, we do not regard her cognitive and linguistic problems as resulting from motor impairment. Likewise, in the 22q11.2 Duplication Syndrome, verbal delay is usually in line with the observed cognitive and pragmatic deficits (Courtens, 2008, Dupont, 2014).

\section{References}

- Boehm, A. (2003). Boehm-3 preescolar. Test Boehm de conceptos básicos. Pearson Clinical Ediciones.

- $\quad$ Bluma, S., Shearer, M., Frohman, A. \& Hilliard, J. (2004). Guía Portage revisada. TEA Ediciones.

- Chandrasekaran, B., Yi, H.G., Blanco, N.J., McGeary, J.E. \& Maddox, W.T. (2015) Enhanced procedural learning of speech sound categories in a genetic variant of FOXP2, Neuroscience, $35 \quad$ (20), 7808-12. https://doi.org/10.1523/JNEUROSCI.4706-14.2015.

- Chang, J., Zhao, L., Chen, Ch., Peng, Y., Xia, Y., Tang, G., Bai, T., Zhang, Y., Ma, R., Guo, R., Mei, L., Liang, D., Cao, Q. \& Wu, L. (2015). Pachygyria, seizures, hypotonia and grown retardation in a patient with an atypical $1.33 \mathrm{Mb}$ inherited microduplication at 22q11.23. Gene, 569, 46-50. https://doi.org/10.1016/j.gene.2015.04.090 
- Chiu, Y.C., Li, M.Y., Liu YH, Ding JY, Yu JY, Wang TW (2014) Foxp2 regulates neuronal differentiation and neuronal subtype specification. Dev Neurobiol. 74, 723-738. https: //doi.org/10.1002/dneu.22166

- Courtens, W., Schramme, I., Laridon, A., (2008). Microduplication 22q11.2: a benign polymorphism or a syndrome with a very large clinical variability and reduced penetrance? report of two families. Am. J. Med. Genet. A 146A, 758763. https: //doi.org/ 10.1002/ajmg.a.31910.

- de la Rochebrochard, C., Jolu-Hélas, G., Goldenberg, A., Durand, I., Laquerrière, A., Ickowicz, V., Saugier-Veber, P., Eurin, D., Moirot, H., Diguet, A., de Kergal, F., Tiercin, C., Mace, B., Marpeau, L.\& Frebourg, T. (2006). The intrafamilial variability of the 22q11.2 microduplication encompasses a spectrum for minor cognitive deficits to severe congenital anomalies, Am. J. Med. Genet. A 140 (14), 1608-1613. https: //doi.org/10.1002/ajmg.a.31227

- De Renzi, E. \& Faglioni, P. (1978). Normative data and screening power of a shortened version of the Token Test 1, Cortex, 14-1, 41-49. https: //doi.org/10.1016/S0010-9452(78)80006-9

- Dunn, L., Dunn, L. M., \& Arribas, D. (2006). Peabody, test de vocabulario en imágenes. TEA Ediciones.

- Dupont, C., Grati, F.R., Choy, K., Jaillard, S., Toutain, J., Maurin, M.L., Martínez-Conejero, Beneteau, C., Coussement, A., Molina-Gomes, L., Nina, D., Horelli-Kuitunen, A., Tabet, A.C., Besseau-Ayasse, J., Bessieres-Grattagliano, B., Giuseppe,S., Gustavo Ayala, S., Benzacken, B. \& Vialard, F.(2014). Prenatal diagnosis of 24 cases of microduplication 22 q11.2: an investigation of phenotypegenotype correlations. Prenatal Diagnosis, 35 (1), 35-43. https: //doi.org/10.1002/pd.4478. 
- Du, Q., de la Morena, M.T., van Oers, N.S.C. (2020). The Genetics and Epigenetics of 22q11.2 Deletion Syndrome. Front Genet, 6, 10:1365. https: //doi.org/10.3389/fgene.2019.01365.

- Ensenauer, R.E., Ensenauer, R.E., Adeyinka, A., Flynn, H.C., Michels, V.V., Lindor, N.M., Dawson, D.B., Thorland, E.C., Lorentz, C.P., Goldstein, J.L., McDonald, M.T., Smith, W.E., Simon-Fayard, E., Alexander, A.A., Kulharya, A.S., Ketterling, R.P., Clark, R.D., Jalal, S.M., (2003). Microduplication 22q11.2, an emerging syndrome: clinical, cytogenetic, and molecular analysis of thirteen patients. Am. J. Hum. Genet. 73, 1027-1040. https: //doi.org/10.1086/378818

- García-Bellido, P., Benítez Burraco, A, Roselló, M., Monfort, S., Martínez, F., Oltra, S., Quiroga, R. \& Orellana, C. (2009). A case of spanish language disorders with a rare genetic cause, En Victoria Marrero \& Idaira Pineda (Eds.) La Lingüística ante el reto de la aplicación clínica. Actas del II Congreso Internacional de Lingüística Clínica. Madrid: Euphonia Ediciones.

- García-Calero, E., Botella-López, A., Bahamonde, O., Pérez-Balaguer, A. \& Martínez, S. (2016). FoxP2 protein levels regulate cell morphology changes and migration patterns in the vertebrate developing telencephalon. Brain Struct. Funct. 221, 2905-2917. https://doi.org/10.1159/000446601

- Gialluisi, A., Visconti, A., Willcutt, E.G., Smith, S.D., Pennington, B.F., Falchi, M., DeFries, J.C., Olson, R.K., Francks, C. \& Fisher, S.E. (2016). Investigating the effects of copy number variants on reading and language performance. $J$ Neurodev Disord, 8, 15-17. https://doi.org/10.1186/s11689-016-9147-8.

- Gimelli, S., Capra, V., Di Rocco, M., Leoni, M., Mirabelli-Madenier, M., Schiaffino, M. C., Fiorio, P., Cuoco, C., Gimelli, G.\& Tassano, E. (2014). Interstitial 7q31.1 copy number variations disrupting IMMP2L gene are 
associated with a wide spectrum of neurodevelopmental disorders, Mol Cytogenet., 13, 7-54. https://doi.org/10.1186/s13039-014-0054-y.

- Graham, S.A., Deritiotis, P., Fisher, S.E. (2015). Insights into the genetic foundations of human communication. Neuropsychol. Rev., 25(1), 3-26. https://doi.org/10.1007/s11065-014-9277-2.

- Kirk, S., McCarthy, J., \& Kirk, W. (2009). Test de Illinois de Aptitudes Psicolingüísticas (7ma edición. ed.) Madrid: TEA Ediciones.

- Kurt, S., Fisher, S.E. \& Ehret, G. (2012) Foxp2 mutations impair auditory-motor association learning, PLoS One, 3, 33130 https://doi.org/10.1371/journal.pone.0033130

- Kylat, R. (2018). 22q11.2 Microduplication: An Enigmatic Genetic Disorder. Journal of pediatrics genetics, 7 (3), 138-141. https://doi.org/10.1055/s-00381655754

- $\quad$ Laffin, J.J, Raca, G, Jackson, C.A, Strand, E.A, Jakielski, K.J \& Shriberg L, D. (2012). Novel candidate genes and regions for childhood apraxia of speech identified by array comparative genomic hybridization. Genetics in Medicine,14, 928-36. https://doi.org/10.1038/gim.2012.72

- Lennon, P.A., Cooper, M.L., Peiffer, D.A., Gunderson, K.L., Patel, A., Peters, S., Cheung, S.W. \& Bacino, C.A. (2007). Deletion of 7q31.1 supports involvement of FOXP2 in language impairment: clinical report and review, American Journal of Medical Genetics, part A, 143 A (8), 791-798. https://doi.org/10.1002/ajmg.a.31632

- Martínez-Urquiza, M., Díaz-Martínez, F., Moreno-Campos, V., Simón-López, T. \& Lázaro-López, M. (2015). Protocolo Rápido de Evaluación PragmáticaRevisado. Valencia: Universitat de València. 
- Monfort, M., \& Juarez, A. (1988). Registro fonológico inducido. Revista de Logopedia, Foniatría y Audiología, 8(2), 88-96. https://doi.org/10.1016/S02144603(88)75430-3

- Moralli, D., Nudel, R., Chan M.T., Green, C.M., Volpi, E.M., Benítez-Burraco, A., Newbury, D.F. \& García-Bellido, P. (2015). Language impairment in a case of a complex chromosomal rearrangement with a breakpoint downstream of FOXP2, Molecular Cytogenetics, 8:36. https://doi.org/10.1186/s13039-0150148-1

- Morgan, A., Fisher, S.E., Scheffer, I. \& Hildebrand, M. (2016). FOXP2-Related Speech and Language Disorders. In: M.P. Adam, H.H Ardinger, R.A. Pagon et al., editors. Seattle (WA): University of Washington.

- Palka, C., Alfonsi, M., Mohn, A., Cerbo, R., Guanciali-Franchi, P., Fantasía, D., Morizio, E., Stuppia, L., Calabrese, G., Zori, R., Chiarelli, F.\& Palka, G. (2011). Mosaic 7q.31 deletion involving FOXP2 gene associated with language impairment. Pediatrics, 129 (1), e183-188. https://doi.org/10.1542/peds.20102094.

- Puvabanditsin, S., Garrow, E., February, M., Yen, E. \& Mehta, R. (2015). Esophageal atresia with recurrent tracheoesophageal fistulas and microduplication 22q11.23. Genetic Counseling, 26 (3), 313-320.

- $\quad$ Rieger, M., Krumbiegel, M., Reuter, M.S., Schützenberger, A, Reis, A. \& Zweier, C. (2020) $7 \mathrm{q} 31.2 \mathrm{q} 31.31$ deletion downstream of FOXP2 segregating in a family with speech and language disorder. Am J Med Genet A., 182(11), 2737-2741. https://doi.org/10.1002/ajmg.a.61838.

- Schreiweis, C., Bornschein, U., Burguière, E., Kerimoglu, C., Schreiter, S., Dannemann, M., Goyal, S., Rea, E., French, C.A., Puliyadi, R., Groszer, M., 
Fisher, S.E., Mundry, R., Winter, C., Hevers, W., Pääbo, S., Enard, W. \& Graybiel, A.M. (2014) Humanized Foxp2 accelerates learning by enhancing transitions from declarative to procedural performance. Proc Natl Acad Sci US A. 111(39), 14253-8. https://doi.org/10.1073/pnas.1414542111.

- Shriberg, L.D., Ballard, K.J., Tomblin, J.B., Duffy, J.R., Odell. K.H. \& Williams, C.A. (2006). Speech, prosody and voice characteristics of a mother and daughter with a 7,13 translocation affecting FOXP2, Journal of Speech Language and Hearing Research, 49 (3), 500-525. https://doi.org/10.1044/1092-4388 $(2006 / 038)$

- Solot, C.B., Sell, D., Mayne, A., Baylis, A.L., Persson, C., Jackson, O. \& McDonald-McGinn, D.M. (2019). Speech-Language Disorders in 22q11.2 Deletion Syndrome: Best Practices for Diagnosis and Management. Am J Speech Lang Pathol, 9, 28(3), 984-999. https://doi.org/10.1044/2019_AJSLP-16-0147.

- Sullivan, K.E. (2019). Chromosome 22q11.2 deletion syndrome and DiGeorge syndrome, Immunol Rev, 287 (1),186-201. https://doi.org/10.1111/imr.12701.

- $\quad$ Tsui, D., Vessey, J.P., Tomita, H., Kaplan, D.R. \& Miller, F.D. (2013) Foxp2 regulates neurogenesis during embryonic cortical development. Journal of Neuroscience. 33, 244-258. https://doi.org/10.1523/JNEUROSCI.1665-12.2013

- $\quad$ Turner, S.J., Hildebrand, M.S., Block, S., Damiano, J., Fahey, M., Reilly, S., Bahlo, M., Scheffer, I.E, Morgan, A.T. (2016). Small intragenic deletion in FOXP2 associated with childhood apraxia of speech and dysarthria. American Journal of Medicine and Genetics, 161A, 2321-2326. https://doi.org/10.1002/ajmg.a.36055

- Valencia-Peña, C., Jiménez-Sánchez, N, Saldarriaga, W. \& Payán-Gómez, C. (2020). Optic nerve coloboma as extension for the phenotype of 22q11.23 
duplication syndrome: a case report. BMC Ophthalmology, 20:333. https://doi.org/10.1186/s12886-020-01603-w

- Vargha-Khadem, F., Gadian, D.G., Copp, A. \& Mishkin, M. (2005) FOXP2 and the neuroanatomy of speech and language. Nature Rev Neurosci., 6, 131-138.

- Yu, A., Turbiville, D., Xu, F., Ray, J. W., Britt, A. D., Lupo, P. J., Jain, S., Shattuck, K., Robinson, S. \& Dong, J. (2019). Genotypic and phenotypic variability of 22q11.2 microduplications: An institutional experience. American Journal of Medical Genetics $179 \quad$ A, 2178-2189. https://doi.org/10.1002/ajmg.a.61345

- Zeesman, S., Nowaczyk, M.J., Teshima, I., Roberts, W., Cardy, J.O., Brian, J., Senman, L., Feuk, L., Osborne, L.R. \& Scherer, S.W. (2006). Speech and language impairment and oromotor dyspraxia due to deletion of $7 \mathrm{q} 31$ that involves FOXP2, American Journal of Medical Genetics, 140 (5), 509-514. https://doi.org/10.1002/ajmg.a.31110

- Zhao, J., Noon, S.E., Krantz, I.D \& Wu, Y. (2016) A de novo interstitial deletion of 7q31.2q31.31 identified in a girl with developmental delay and hearing loss. Am J Med Genet C Semin Med Genet., 172(2), 102-8. https://doi.org/10.1002/ajmg.c.31488.

- Zinkstok, J.R., Boot, E., Bassett, A.S., Hiroi, N., Butcher, N.J., Vingerhoets, C., Vorstman, J.A.S. \& van Amelsvoort, TA.MJ. (2019). Neurobiological perspective of 22q11.2 deletion syndrome. Lancet Psychiatry, 6 (11), 951-96. https://doi.org/10.1016/S2215-0366(19)30076-8. 
Table 1.

\begin{tabular}{|c|c|c|}
\hline & Description & Meaning \\
\hline & Repeated movement of the hand with open palm + closing & More \\
\hline & Repeated movement of the hand with open palm extending & Give me \\
\hline & the arm and bringing it closer to the body. & 'this' \\
\hline & Point to and then point to an object & 'I want' \\
\hline
\end{tabular}

Table 1. Gestures proband's inventory: description and meaning.

Table 2.

\begin{tabular}{|c|c|c|c|c|}
\hline Symptoms & Proband & $\begin{array}{l}\text { FOXP2 } \\
\text { mutations }\end{array}$ & $\begin{array}{l}7 \text { q31 Deletion } \\
\text { Syndrome }\end{array}$ & $\begin{array}{l}\text { 22q11.2 Duplication } \\
\text { Syndrome }\end{array}$ \\
\hline \multicolumn{5}{|l|}{ Grown retardation } \\
\hline & & & & $\checkmark$ \\
\hline \multicolumn{5}{|c|}{ Autistic Spectrum disorders } \\
\hline \multicolumn{5}{|l|}{ Auditory problems } \\
\hline Gross motor delay & & & $\checkmark$ & $\checkmark$ \\
\hline Fine motor delay & $\checkmark$ & $\checkmark$ & $\checkmark$ & $\checkmark$ \\
\hline Facial dysmorphology & $\checkmark$ & $\checkmark$ & $\checkmark$ & $\checkmark$ \\
\hline Swallowing disorders & & & & $\checkmark$ \\
\hline Hypotonia & & & $\checkmark$ & $\checkmark$ \\
\hline Intellectual delay & $\checkmark$ & $\checkmark$ & $\checkmark$ & $\checkmark$ \\
\hline Speech delay & & & $\checkmark$ & $\checkmark$ \\
\hline
\end{tabular}




\begin{tabular}{|l|c|c|c|c|}
\hline Spastic dysarthria & $\checkmark$ & $\checkmark$ & & \\
\hline Dyspraxia nonverbal & $\checkmark$ & $\checkmark$ & & $\checkmark$ \\
\hline $\begin{array}{l}\text { Stronger verbal } \\
\text { performance than verbal }\end{array}$ & & & & \\
\hline
\end{tabular}

Table 2. Clinical feature of interest as found in the literature in cases with genetic alterations like the ones found in our proband

Figure 1.

A
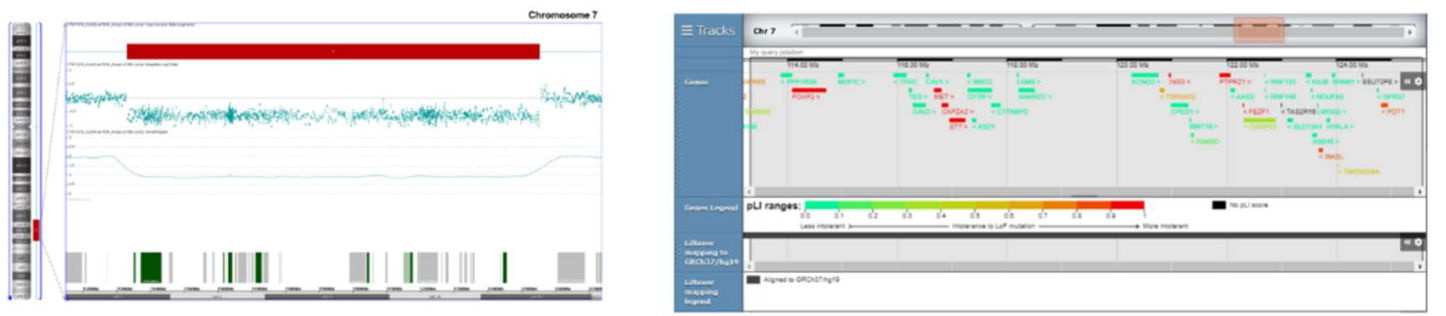

B
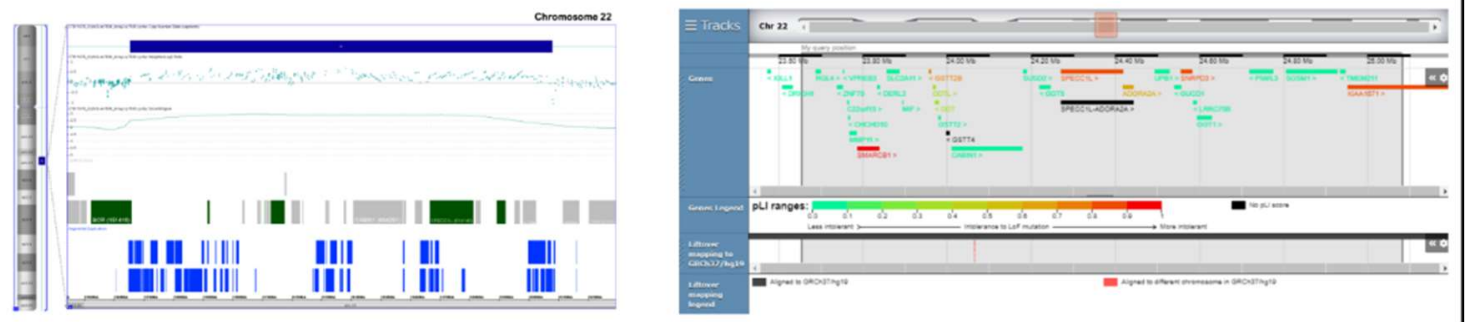

Figure 1. Chromosomal alterations found in our proband. A. Left. Screen capture of the array-CGH of the proband's chromosome 7 showing the microdeletion $7 q 31$. Right. Right. Screen capture of the Decipher Genome Browser (https://decipher.sanger.ac.uk/browser/) showing the genes deleted in the proband. B. Left. Screen capture of the array-CGH of the proband's chromosome 22 showing the microduplication at 22q11.2. Right. Screen capture of the Decipher Genome Browser (https://decipher.sanger.ac.uk/browser/) showing the genes duplicated in the proband. 
Image 2 .

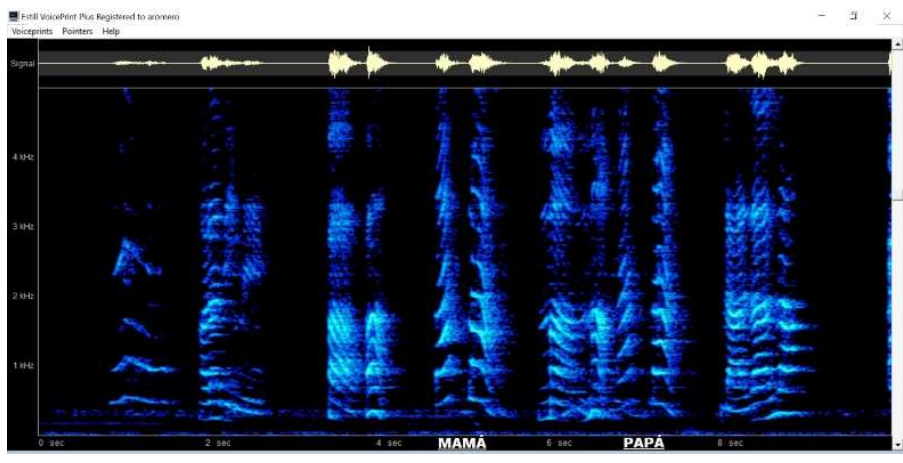

Figure 2. Proband's sample voice analysis by Estill Voiceprint Plus program. 